\title{
An evaluation of the economic and green market utility in a circular economy
}

\author{
Iryna Reshetnikova ${ }^{1}$, Viktoriia Apalkova ${ }^{2}$, Iryna Lytovchenko $^{3, *}$, and Jan W. Wiktor ${ }^{4}$ \\ ${ }^{1}$ National Economic University named after Vadym Hetman, Department of Marketing named after \\ A.F.Pavlenko, 54/1 Peremohy Avenue, Kyiv, Ukraine \\ ${ }^{2}$ National Economic University named after Vadym Hetman, Department of International Economics, \\ 54/1 Peremohy Avenue, Kyiv, Ukraine \\ ${ }^{3}$ Odessa National University of Economics, Head of the Department of Marketing, 8 \\ Preobrazhenskaya str., Odessa, , Ukraine \\ ${ }^{4}$ Cracow University of Economics, ul. Rakowicka 27, 31-510 Kraków, Poland
}

\begin{abstract}
The article focuses on the problem of evaluation of new markets in a circular economy, substantiating the need to assess not only economic performance, but also green utility in the process of making managerial decisions. The article proposes an algorithm for calculating the complex Index of Economic and Green Market Utility (IEGMU) for the region in the field of car sharing. It covers such indicators as market capacity and dynamics, the level of impact on the traditional automotive sector, as well as the green effect, which includes the reduction of carbon dioxide emissions, product (vehicle) consumption, and pressure on transport infrastructure. The advantage of the proposed algorithm is the possibility of using matrix analysis to determine the stage of development of each market. As an approbation, the article presents the calculation of the index for such regions as North America, Europe and Asia.
\end{abstract}

\section{Introduction}

Recently, the world community has sharpened its attention to global environmental problems, overproduction and depletion of natural resources. Management strategic and marketing decisions are made based on their impact on the achievement of the goals of sustainable development of society. Consumer behaviour is becoming more conscientious, and enterprise management must respond to these new trends. In this regard, the demand for new business models that provide circularity and decoupling has increased.

A circular business model responds the question how a company creates and delivers value through logic that increases resource efficiency by extending the useful life of products and parts (for example, through durable design, repair, and refurbishment) and completing the product lifecycle through recycling and capitalizing on their residual value [1-3]. This leads to the gradual separation of economic activity from the consumption of limited resources and the elimination of waste from the system [4]. Product or service systems, which focus on selling service and functionality instead of products, are one of the

\footnotetext{
${ }^{*}$ Corresponding author: reshet2002@gmail.com
} 
primary vehicles for implementing a circular economy (CE) in which economic growth is decoupled from resource consumption. [5].

A bibliometric analysis of the literature has shown that the development of a circular economy is assessed at three levels: micro, meso and macro levels [6, 7]. Macro-level indicators are needed for evaluation and monitoring to improve various programs at the state level [8,9]. Micro-level indicators, as a rule, cover 9R-imperatives [12-14] and analyze environmental friendliness as well as wasteless production and consumption. [1012]. At the same time, most of the studied indicators are focused only on one and (or) several specific environmental problems, which introduces evaluative subjectivity.

The purpose of this article is to form and propose an algorithm for assessing the economic and green utility of the market, based on the example of such a segment of the circular economy as car sharing.

The analysis of the literature on the problems of circularity in industries showed that they are mainly of an applied nature and focus on solving specific technological and organizational issues. At the same time, the issue of creating new value for the consumer in the products of the circular economy remains unaddressed. New trends in consumer behaviour in the post-COVID-19 economy indicate a more pragmatic nature of consumption as well as a desire to preserve the nature and resources of the planet. [13]. These motives in behaviour will dictate new values to producers. Thus, in assessing the prospects of markets, in addition to economic criteria, it is necessary to take into account the parameters of green utility.

Many indicators determine market prospects, as a rule, but in general, they can be divided into three main groups: 1) the physical and monetary volume of the market; 2) growth dynamics; 3) main segments and their dynamics; level of competition [14-15]. However, in connection with global informatization and the development of new business models in the IT sector, the importance of assessing the life cycle of goods and services, as well as the level of applied technologies and potential servitization, has increased in market analysis.

Moreover, large investors paid attention to the problems of the ecology of the planet, which led to a revision of many principles of production, increased requirements, the emergence of new business models and markets associated with a circular economy. In this regard, in order to create long-term business models, it is necessary to understand by what parameters society, the state and investors will assess their value.

Obviously, one can apply individual approach to different markets. In our research, we focused on analyzing the automotive industry market.

According to the most recent estimates, the world's population is a (quickly growing) 7.6 billion, and with an estimated 1.4 billion cars on the road, that puts the vehicle saturation at around $18 \%[16,17]$. At the same time, the global automotive industry market has been increasing annually and, according to some forecasts, will continue to grow in the post-crisis period (due to COVID-19) with an annual growth of $+5 \%$ (for the period from 2021 to 2030 [18]).

It is no secret that a car as a product causes significant damage to the environment consuming significant resources for its production, polluting the air with exhaust gases, stimulating the development of road construction, which in turn also has a number of negative consequences for nature. At the same time, in the modern world, a car is one of the main attributes of a comfortable life as well as is a key element of the transport and logistics infrastructure of the global economy. Thus, one cannot refuse this good, but it is obvious that the requirements for the automotive market should be increased. Since people cannot completely abandon autos, but they can "consume" fewer cars and also use ones that cause minimal damage to the environment. 
One of the main business areas designed to solve these problems is the development of the car sharing market. Car sharing or short-term rental is an option to rent a car from specialized companies (B2C) or individuals (P2P) for any period and distance of travel by agreement (most often for intracity and / or short trips). This car rental model is convenient for occasional use of a motor vehicle or in the case when people need a car that is different from the brand, body type and carrying capacity from the commonly used one.

Car sharing is one of the global trends in the development of the Sharing Economy, when the population refuses to acquire goods in property, so as not to bear responsibility and costs, but continues to have access to all the achievements of scientific progress, using their joint consumption [19]. Car sharing services are available in more than 1000 cities in dozens of countries around the world [20]. Analysis of the market and analytical sources [21] revealed that at the moment the following main business models in this market can be distinguished (Fig. 1).

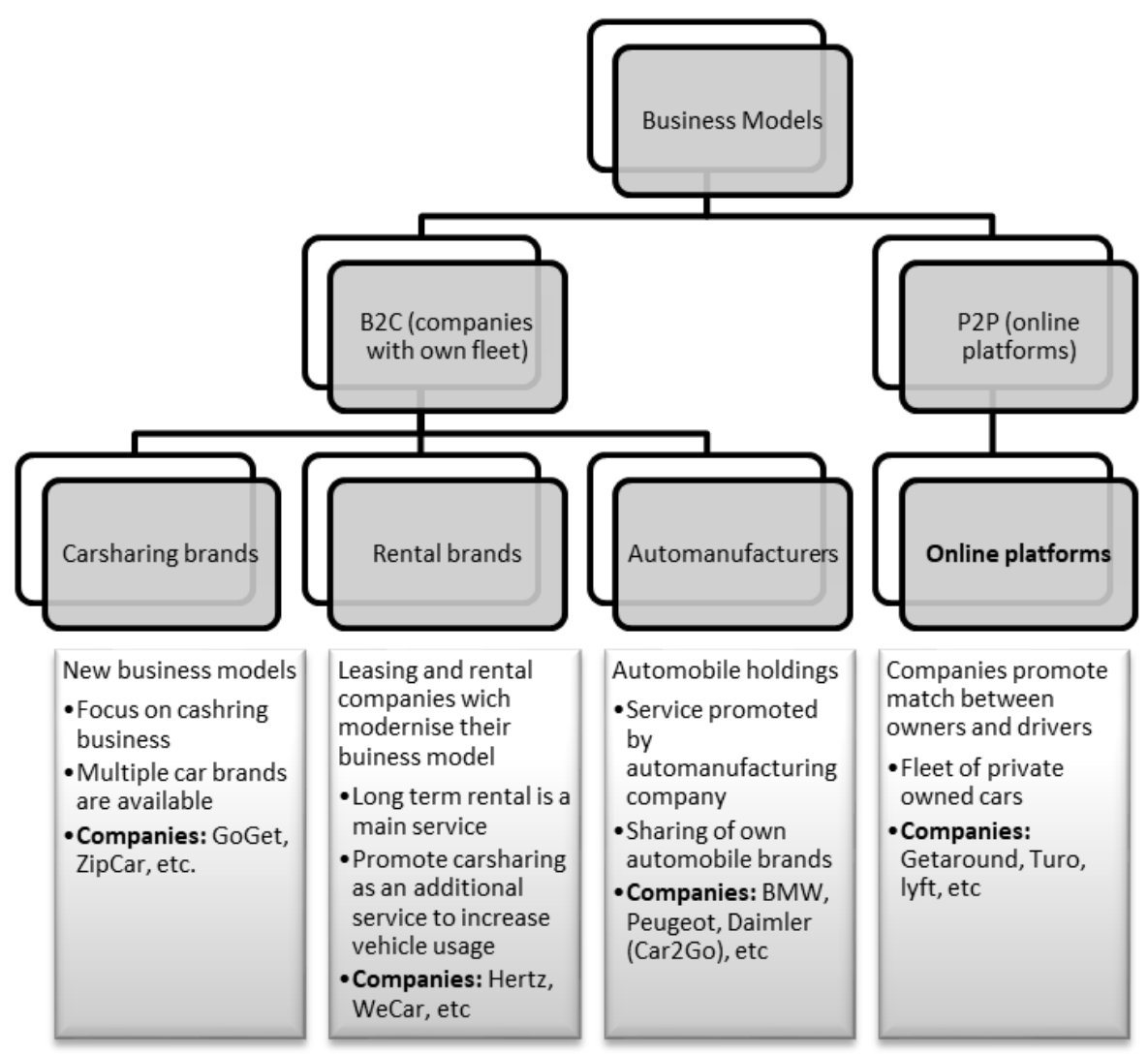

Fig. 1. Main car sharing business models [20-21]

This is a far from complete list of existing models. At the same time, in some countries and regions more and more new business models and companies appear, while in others the existing market operators are being transformed. Therefore, there is a need to assess their effectiveness, not only by traditional socio-economic parameters, but also by their contribution to the creation of a circular economy. 


\section{Model and methods}

It is proposed to consider the approach of the market evaluation based on the integrated Index of economic and green utility of the market $\left(I_{E G}\right)$ for the region. This index will be subdivided into two sub-indices:

1) sub-index of economic attractiveness of the market;

2) sub-index of circularity and green utility of the market.

In turn, each of these sub-indices includes a number of coefficients that differ depending on the industry and the specifics of the activity of its market players.

$$
I_{E G}=S_{E} * a_{E}+S_{\text {Green }} * a_{\text {Green }}
$$

where $S_{E c o n}$ is a sub-index of market economic attractiveness, $a_{E c o n}$ is a specific weight of this sub-index; $S_{G r e e n}$ is a sub-index of green utility of the market, $a_{G r e e n}$ is a specific weight of this sub-index.

The sub-index of the economic attractiveness of the market includes a set of indicators characterizing its capacity, development dynamics, as well as the level of penetration / replacement of the traditional (non-circular market) (in our case, this is the share of car sharing cars in the total vehicle fleet of the region).

The economic efficiency of the market is a very important factor in the development of the industry, because many new business models, which are very promising in terms of circularity and innovation, do not stand up to the market test due to the imbalance of economic indicators and, in the end, disappear or transform (example Autolib [22], City Carshare [23]). Therefore, one of the main economic indicators of the market for new circular technologies is its rapid growth.

With regard to the sub-index of green utility of the market, it is important to ensure a focus on reducing environmental risks and sustainable development without environmental degradation. It is closely related to environmental economics, but has a more politically applied focus. [24].

Thus, the following most important parameters have been identified for this sub-index: 1) reducing the impact on the environment;

2) a decrease in the consumption of traditional products (for example, cars in our case); 3) reducing the impact on other industries (road and urban planning, fuel production, etc.).

The system for filling sub-indexes with indicators is shown schematically in the Figure 2 below.

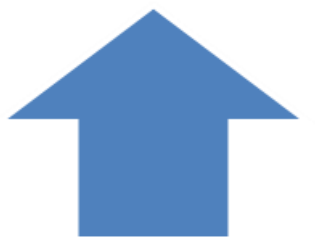

\section{$S_{E}$ - Economic indicators}

- Market capacity

- Growth rate

- Penetration level

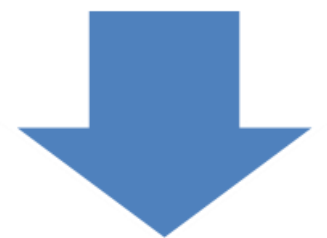

$S_{\text {Green }}$ - Green indicators

-Reducing environmental impact

- Reducing consumption of traditional products (machines)

- Reduced impact on other industries (road and urban planning, fuel production, etc.)

Fig. 2. Scheme of structural filling of sub-indices 
Each sub-index, in our opinion, is very important, so they will have equal shares. As for the indicators that they include, they can have different weights, for example, among the green indicators of the car sharing market, it would be very influential to reduce carbon dioxide emissions and therefore its share of influence should be maximum.

It should be noted that $\mathrm{CO}_{2}$ does not pollute the air people breathe, but it is a main contributor to Global Warming and therefore has to be reduced. [17]. Other emissions from vehicle traffic include:

1) carbon monoxide $(\mathrm{CO})$ is produced by incomplete combustion of carbonaceous fuels and is toxic in high concentrations and therefore needs to be controlled;

2) hydrocarbons (HC) are unburned fuel and can be a problem for people with breathing difficulties, and also contribute negatively to "photochemical smog" in certain climatic conditions;

3) nitrogen oxides (NOx) are formed when the air is heated and contributes to both photochemical smog and acid rain and can irritate the lungs.

Indicators for sub-indexes also have their share in the Index, depending on their importance.

Thus, formula can be rewritten (1) by decomposing the sub-index into indicators that are included in them.

$$
I_{E G}=\sum_{i=1}^{n} E_{i} * a_{i}+\sum_{j=1}^{n} G_{j}^{*} a_{j}
$$

where $\mathrm{E}_{i}$ is an indicator of market economic attractiveness, $a_{i}$ is a specific weight of this indicator; $G_{j}$ is an indicator of green utility of the market, $a_{j}$ is a specific weight of this indicator.

Below is a table with a scale and shares for calculating the Index of Market Economic and Green Utility (IEGMU) and its sub-indices.

Table 1. Evaluation Scale and Weight for the Index of Market Economic and Green Utility (IEGMU) Indicators.

\begin{tabular}{|l|c|c|}
\hline \multicolumn{1}{|c|}{ Indicator } & $\begin{array}{c}\text { Letter } \\
\text { designation }\end{array}$ & $\begin{array}{c}\text { Weight of } \\
\text { sub-index or } \\
\text { indicator }\end{array}$ \\
\hline Sub-index of market economic attractiveness & $\mathrm{S}_{\mathrm{E}}$ & $\mathbf{5 0 \%}$ \\
\hline Customer penetration per capita & $\mathrm{E}_{1}$ & $12,5 \%$ \\
\hline Growth of customer penetration (CAGR*) & $\mathrm{E}_{2}$ & $12,5 \%$ \\
\hline Penetration of carsharing vehicles in total vehicles in use & $\mathrm{E}_{3}$ & $12,5 \%$ \\
\hline Growth of number of carsharing vehicles (CAGR ${ }^{*}$ ) & $\mathrm{E}_{4}$ & $12,5 \%$ \\
\hline Sub-index of green utility of the market & $\mathrm{S}_{\mathrm{Green}}$ & $\mathbf{5 0 \%}$ \\
\hline Number of vehicles replaced by one carsharing vehicle & 1 & $15 \%$ \\
\hline $\begin{array}{l}\text { Reduction of carbon dioxide emissions per year in metric } \\
\text { tons }\end{array}$ & 2 & $15 \%$ \\
\hline $\begin{array}{l}\text { Reduction of carbon dioxide emissions per year (per } 1000 \\
\text { inhabitants) }\end{array}$ & 3 & $20 \%$ \\
\hline
\end{tabular}

$C A G R$ - Compound Annual Growth Rate is calculated by formula (3):

$$
\text { CAGR }=\left[\left(\frac{\text { Ending Value }}{\text { Beginning Value }}\right)^{1 / \text { Number of Years }-1] * 100 \%}\right.
$$

The Index value range (IEGMU) determines the degree of investment attractiveness of the market in terms of economic and green indicators and provides a good tool for comparing this parameter across different regions. Thus, the higher the Index, the more investment attractive is the market of a given region in comparison with other territories. 
At the same time, an important component is the ratio of the contribution of sub-indices: after all, the market can actively develop in terms of economic parameters, but bring a relatively low green effect, and vice versa, with moderate market growth, but qualitative transformations, its green utility can increase. In this regard, it would be purposeful to use matrix analysis.

Table 2. Evaluation Matrix of the level of investment attractiveness of the region's market based on the economic and green indicators of the Index of Market Economic and Green Utility.

\begin{tabular}{|c|c|c|l|}
\hline IEGMU & $\begin{array}{c}\text { Sub-index of } \\
\text { market } \\
\text { economic } \\
\text { attractiveness }\end{array}$ & $\begin{array}{c}\text { Sub-index } \\
\text { of green } \\
\text { utility of } \\
\text { the market }\end{array}$ & Market \\
\hline Low & Low & Low & $\begin{array}{l}\text { The market is in its infancy. Experimenting with } \\
\text { business models. High risk of bankruptcy. The } \\
\text { market is fragmented and does not have a } \\
\text { significant green effect. }\end{array}$ \\
\hline Medium & High & Low & $\begin{array}{l}\text { The market is in the stage of active growth. } \\
\text { Extensive market development is observed, } \\
\text { which, however, creates a minimal green effect }\end{array}$ \\
\hline Medium & Low & High & $\begin{array}{l}\text { The market has entered the stage of saturation or } \\
\text { is simply growing slowly compared to other } \\
\text { regions (perhaps there are certain obstacles, for } \\
\text { example, the car-sharing business model is not } \\
\text { supported at the local level). At the same time, its } \\
\text { green indicators, such as reducing CO }{ }_{2} \text { emissions } \\
\text { per capita, are significantly ahead of other } \\
\text { regional markets. }\end{array}$ \\
\hline High & High & High & $\begin{array}{l}\text { The regional market is leading in terms of growth } \\
\text { and economic development as well as creates the } \\
\text { maximum green effect compared to other } \\
\text { countries (regions). }\end{array}$ \\
\hline
\end{tabular}

Evaluating local markets according to these criteria makes it possible to classify them according to the degree of economic and green utility and predict changes.

\section{Results and discussions}

To test the proposed methodological approach, world statistics on the car sharing market have been collected. It should be noted that due to the fact that the industry is young, statistical data, in a more or less complete and homogeneous structure, are available on the Shared Mobility website only for the period from 2007 to 2016 [19]. However, given that the purpose of the article is not to identify modern trends, but to propose an algorithm for assessing new markets in the circular economy, we decided to take the statistical data of this resource as a basis. As of the end of 2016, the car-sharing market was actively developing in Asia, Europe and North America. In general, the same trend continued in the next four years [25]. The calculation results are presented in Table 3 below.

It is necessary to dwell separately on the issue of calculating green indicators, in particular, those that are responsible for reducing carbon dioxide emissions. According to the data of United States Environmental Protection Agency [26], a "typical passenger vehicle emits about 4.6 metric tons of carbon dioxide per year. This number can vary based on a vehicle's fuel, fuel economy, and the number of miles driven per year". Considering that the majority of cars in the cashiering market are passenger cars, and, accordingly, they also replace passenger vehicles in personal ownership, this value was taken as a starting point. 
Table 3. Calculation of key indicators for Index of Market Economic and Green Utility (IEGMU) as of 01.01.2017

\begin{tabular}{|c|c|c|c|c|c|}
\hline Region & $\begin{array}{c}\text { Calculation } \\
\text { formula }\end{array}$ & $\begin{array}{c}\text { North } \\
\text { America }\end{array}$ & Europe & Asia & World \\
\hline \multicolumn{6}{|c|}{ Sub-index of market economic attractiveness $\left(\mathrm{S}_{\mathrm{E}}\right)$} \\
\hline Carsharing members (ths) [19] & $(1)$ & 1838 & 4371 & 8722 & 14931 \\
\hline Population (mln) [16] & (2) & 583 & 746 & 4561 & 7631 \\
\hline $\begin{array}{l}\text { Customer penetration per } \\
\text { capita, } E_{1}\end{array}$ & $(3)=(1) /(2)$ & 3,2 & 5,9 & 1,9 & 2,0 \\
\hline $\begin{array}{l}\text { Growth of customer penetration } \\
\text { in } \%, E_{2}\end{array}$ & (4) & $25 \%$ & $32 \%$ & $90 \%$ & $41 \%$ \\
\hline $\begin{array}{l}\text { Number of carsharing vehicles } \\
\text { (ths) [19] }\end{array}$ & (5) & 27 & 58 & 67 & 152 \\
\hline $\begin{array}{l}\text { Motorization rate (per } 1000 \\
\text { inhabitants) [17] }\end{array}$ & (6) & 670 & 581 & 105 & 182 \\
\hline $\begin{array}{l}\text { Number of total vehicles in use } \\
(\mathrm{mln})[17]\end{array}$ & $\begin{array}{c}(7)=(2) / 1000 * \\
(6)\end{array}$ & 391 & 434 & 479 & 1389 \\
\hline $\begin{array}{l}\text { Share of carsharing vehicles in } \\
\text { total vehicles in use, } E_{3}\end{array}$ & $(8)=(7) /(5)$ & $0,007 \%$ & $0,013 \%$ & $\begin{array}{c}0,014 \\
\%\end{array}$ & $0,011 \%$ \\
\hline $\begin{array}{l}\text { Growth of number of carsharing } \\
\text { vehicles in, } E_{4}\end{array}$ & (9) & $18 \%$ & $4 \%$ & $58 \%$ & $26 \%$ \\
\hline \multicolumn{6}{|c|}{ Sub-index of circularity and green utility of the market $\left(\mathrm{S}_{\mathrm{Green}}\right)$} \\
\hline $\begin{array}{l}\text { Number of vehicles replaced by } \\
\text { one casharing vehicle, } 1\end{array}$ & $(10)=(1) /(5)$ & 69 & 76 & 130 & 98 \\
\hline $\begin{array}{l}\text { Reduction of carbon dioxide } \\
\text { emissions per year**, } 2 \text { (ths } \\
\text { metric tons) [26] }\end{array}$ & $\begin{array}{c}(11)=(10)^{*} \mathrm{C} \\
\text { (Dioxide) }\end{array}$ & 8454 & 20107 & $\begin{array}{c}40 \\
122\end{array}$ & 68683 \\
\hline $\begin{array}{l}\text { Reduction of carbon dioxide } \\
\text { emissions per year (per } 1000 \\
\text { inhabitants) }\end{array}$ & $\begin{array}{c}(12)=(11) /(2)^{*} \\
1000\end{array}$ & 14,5 & 26,9 & 8,8 & 9,0 \\
\hline
\end{tabular}

\section{* CAGR of last 10 years}

Based on the calculations obtained, a rating of the regions for each of the indicators have been compiled. The region with the best score out of three received 3 points, second place - 2 points and third place - 3 points. Then, applying formula (2), it was possible to calculate of Index of Market Economic and Green Utility and its sub-indices for each of the regions (Table 4).

Table 4. Calculation of Index of Market Economic and Green Utility (IEGMU) for North America, Europe and Asia*

\begin{tabular}{|c|c|c|c|}
\hline Rating & North America & Europe & Asia \\
\hline$E_{1}$ & 1 & 3 & 2 \\
\hline$E_{2}$ & 1 & 2 & 3 \\
\hline$E_{3}$ & 1 & 2 & 3 \\
\hline$E_{4}$ & 2 & 1 & 3 \\
\hline $\boldsymbol{S}_{\boldsymbol{E}}$ & $\mathbf{0 , 6 3}$ & $\mathbf{1 , 0 0}$ & $\mathbf{1 , 3 8}$ \\
\hline$G_{1}$ & 1 & 2 & 3 \\
\hline$G_{2}$ & 2 & 3 & 1 \\
\hline$G_{3}$ & 2 & 3 & $\mathbf{0 , 8 0}$ \\
\hline $\boldsymbol{S}_{\text {Green }}$ & $\mathbf{0 , 8 5}$ & $\mathbf{1 , 3 5}$ & $\mathbf{1 , 1}$ \\
\hline $\begin{array}{c}\boldsymbol{S}_{\text {Green }} \\
\text { (IEGMU) }\end{array}$ & $\mathbf{0 , 5 3}$ & $\mathbf{1 , 3 5}$ & \\
\hline
\end{tabular}

*As of 01.01.2017 
Thus, the Index of Market Economic and Green Utility calculation showed that the most developed car-sharing market in Europe, moreover, it provides the highest level of green indicators. It is important to understand that this is achieved due to the relevance of reducing the number of car owners, because here is one of the highest levels in terms of per 1000 inhabitants. In second place is the car-sharing market in Asia, where it demonstrates a high level of growth, but does not have such a high effect in terms of green indicators, the main reason is that personal vehicles are not as affordable here as in Europe. The USA has the lowest index. Despite the fact that the largest P2P car sharing platforms are located here, the overall level of penetration and growth of the car sharing market remains one position lower than in previous regions. Based on the calculated data, a matrix for evaluating of the Index of Market Economic and Green Utility index by region was built.

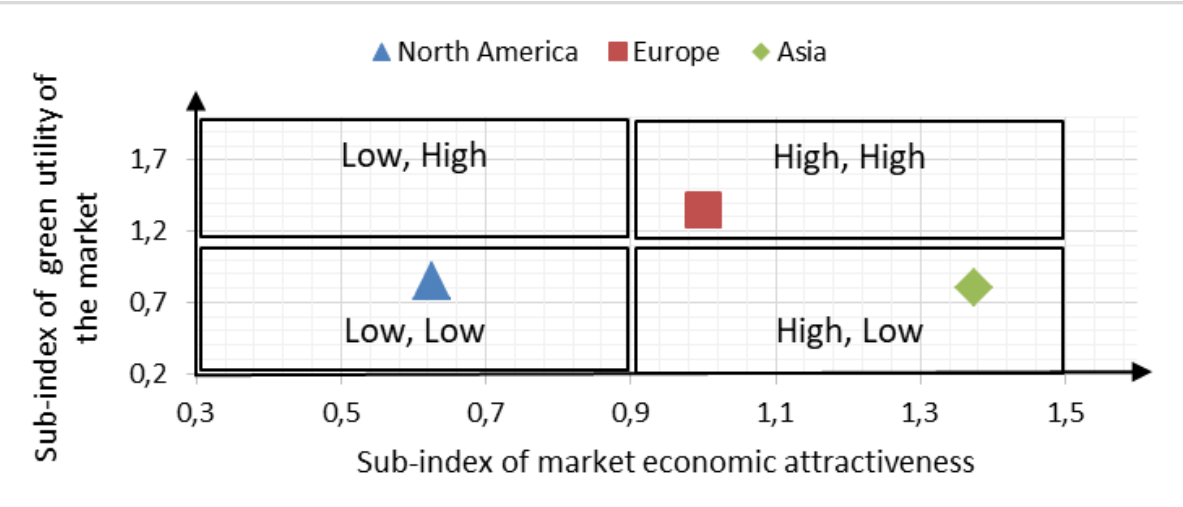

Fig. 3. Matrix for Evaluation of Index of Market Economic and Green Utility by region Source: developed by authors

As one can see, the European car-sharing market is in the quadrant of high overall economic and green utility, while the Asian market is in the quadrant of high economic attractiveness, but low green return, and North America is in the lowest zone for both parameters.

\section{Conclusions}

The ideas of a circular economy and changes in consumer behavior have impacted virtually all product markets. Currently, the car sharing market, as one of the examples of business models of the circular economy, is actively developing in different regions. To analyze market development and assess its investment attractiveness, we need tools that will be based not only on economic efficiency, but also on green utility.

The Index of Economic and Green Market Utility proposed by the authors allows to make such a comparative analysis of local car-sharing markets. It can be calculated annually in order to have an idea of the progress that each country is making in building its own market. The advantage of the proposed algorithm is the possibility of using matrix analysis to understand at what stage of development each market is, and most importantly, in which direction it is possible to improve circular business models. In addition, this algorithm is flexible enough to include other green indicators. For example, in the future, as the statistical base is filled, the sub-index of green utility can be supplemented with such indicators as: 1) participants who sold private vehicle after joining carcharing (\%), participants who postponed or avoided vehicle purchase because of carsharing (\%), vehicle kilometers reduced because of carsharing (\%). 
The Index of Economic and Green Market Utility is a convenient tool for assessing the state of development of the car-sharing market in order to determine the effectiveness of government measures to stimulate market participants.

\section{References}

1. Bocken, N. M., De Pauw, I., Bakker, C., \& Van Der Grinten, B. (2016). Product design and business model strategies for a circular economy. Journal of Industrial and Production Engineering, 33(5), 308-320.

2. Bakker, C., den Hollander, M., Van Hinte, E., \& Zijlstra, Y. (2019). Products that Last 2.0: Product Design for Circular Business Models. BIS Publishers.

3. Nußholz, J. L. (2017). Circular business models: Defining a concept and framing an emerging research field. Sustainability, 9(10), 1810.

4. Scheel, C., Aguiñaga, E., \& Bello, B. (2020). Decoupling Economic Development from the Consumption of Finite Resources Using Circular Economy. A Model for Developing Countries. Sustainability, 12(4), 1291.

5. Kjaer, L. L., Pigosso, D. C., Niero, M., Bech, N. M., \& McAloone, T. C. (2019). Product/service-systems for a circular economy: The route to decoupling economic growth from resource consumption? Journal of Industrial Ecology, 23(1), 22-35.

6. Moraga, G., Huysveld, S., Mathieux, F., Blengini, G. A., Alaerts, L., Van Acker, K., ... \& Dewulf, J. (2019). Circular economy indicators: What do they measure? Resources, Conservation and Recycling, 146, 452-461.

7. Elia, V., Gnoni, M. G., \& Tornese, F. (2017). Measuring circular economy strategies through index methods: A critical analysis. Journal of Cleaner Production, 142, 27412751.

8. Merli, R., Preziosi, M., \& Acampora, A. (2018). How do scholars approach the circular economy? A systematic literature review. Journal of Cleaner Production, 178, 703-722.

9. Ghisellini, P., Cialani, C., \& Ulgiati, S. (2016). A review on circular economy: the expected transition to a balanced interplay of environmental and economic systems. Journal of Cleaner production, 114, 11-32.

10. Pomponi, F., \& Moncaster, A. (2017). Circular economy for the built environment: A research framework. Journal of cleaner production, 143, 710-718.

11. Prieto-Sandoval, V., Jaca, C., \& Ormazabal, M. (2018). Towards a consensus on the circular economy. Journal of cleaner production, 179, 605-615.

12. Lewandowski, M. (2016). Designing the business models for circular economyTowards the conceptual framework. Sustainability, 8(1), 43.

13. Smerichevskyi, S., Kniazieva, T., Kolbushkin, Y., Reshetnikova, I., \& OlejniczukMerta, A. (2018). Environmental orientation of consumer behavior: motivational component. Problems and Perspectives in Management, 16(2), 424.

14. Day, G. S. (1981). Strategic market analysis and definition: an integrated approach. Strategic Management Journal, 2(3), 281-299.

15. Bhattacharyya, S., \& Nain, A. (2011). Horizontal acquisitions and buying power: A product market analysis. Journal of Financial Economics, 99(1), 97-115.

16. World Bank Data (2020). Population. https://data.worldbank.org/indicator

17. International Organization of Motor Vehicle Manufacturers. Official website. https://www.oica.net/world-vehicles-in-use-all-vehicles-2/ 
18. Laborda, J., \& Moral, M. J. (2020). Automotive Aftermarket Forecast in a Changing World: The Stakeholders' Perceptions Boost!. Sustainability, 12(18), 7817.

19. Carsharing Market Analysis: Growth and Industry Analysis (2018) Retrieved from https:/www.sharedmobility.news/carsharing-market-analysis-growth-industry-analysis

20. Deloitte Monitor (2017). Car Sharing in Europe: Business Models, National Variations and Upcoming Disruptions. (p. 2-8). https://www2.deloitte.com/content

21. Geissdoerfer, M., Morioka, S. N., de Carvalho, M. M., \& Evans, S. (2018). Business models and supply chains for the circular economy. Journal of cleaner production, 190, 712-721.

22. Byun, W., Lee, J. B., Kee, H., \& Do, M. (2017). Characteristics of closed car-sharing services for urban public housing residents. Journal of Science and Technology Policy Management.

23. Kortum, K., Schönduwe, R., Stolte, B., \& Bock, B. (2016). Free-floating carsharing: City-specific growth rates and success factors. Transportation Research Procedia, 19, 328-340.

24. Kahle, L. R., \& Gurel-Atay, E. (2014). Introduction to the psychology of communicating sustainability. Communicating sustainability for the green economy, 321.

25. Statista (2020). Car-sharing in Europe. https://www.statista.com

26. United States Environmental Protection Agency (n.d.). Greenhouse Gas Emissions from a Typical Passenger Vehicle. https://www.epa.gov/greenvehicles 